\title{
ETIKA BISNIS ISLAMI DALAM PRAKTEK BISNIS RASULULLAH
}

\author{
Muhammad Saifullah \\ IAIN Walisongo Semarang \\ e-mail:say_full2003@yahoo.com
}

\begin{abstract}
Historical study of the Muhammad's behavior and business ethics before being appointed as messenger is an interesting study, because the conduct and business ethics that Mohammed applied was based on the study of the verses of the Koran. After appointed as messenger (40 years old), the life of prophet Muhammad was more guided by the revelations of the Qur'an. Some principles which the prophet applied are honest, amanah, accurate in weighting, , avoid gharar, not hoard goods, not execute al-ghab and tadlis among seller and buyer.

$* * *$

Kajian sejarah mengenai perilaku dan etika bisnis Muhammad sebelum ditunjuk sebagai nabi merupakan kajian yang menarik, karena peri laku dan etika bisnis yang diterapkan oleh Muhammad didasarkan pada kajian ayat-ayat al-Qur'an. Setelah ditunjuk sebagai nabi (usia 40 tahun), kehidupan Nabi Muhammad lebih dibimbing oleh wahyu-wahyu al-Qur'an. Beberapa prinsip yang diterapkan oleh Muhammad adalah jujur, amanah, timbangan yang tepat, menghindari gharar, tidak menimbun barang, tidak melakukan al-ghalb dan tadlis di antara penjual dengan pembeli.
\end{abstract}

Keywords: etika, moral, bisnis, Muhammad, perilaku, ekonomi 


\section{A. Pendahuluan}

Selama ini banyak orang memahami bisnis adalah bisnis, yang tujuan utamanya memperoleh keuntungan sebanyak-banyaknya. Hukum ekonomi klasik yang mengendalikan modal sekecil mungkin dan mengeruk keuntungan sebesar mungkin telah menjadikan para 'pelaku bisnis' menghalalkan segala cara untuk meraih keuntungan, mulai dari cara memperoleh bahan baku, bahan yang digunakan, tempat produksi, tenaga kerja, pengelolaannya, dan pemasarannya dilakukan seefektif dan seefesien mungkin. Hal ini tidak mengherankan jika para pelaku bisnis jarang memperhatikan tanggungjawab sosial dan mengabaikan etika bisnis.

Etika bisnis dalam studi Islam selama ini kajiannya lebih didasarkan pada al-Qur'an. Padahal Muhammad dalam tinjauan sejarah dikenal sebagai pelaku bisnis yang sukses, sehingga kajian tentang etika bisnis perlu melihat perilaku bisnis Muhammad semasa hidupnya. Mental pekerja keras Muhammad dibentuk sejak masa kecil sewaktu diasuh Halimah Assa'diyah hingga dewasa. Bersama anak-anak Halimah, Muhammad yang saat itu berusia 4 tahun menggembala kambing. Pengalaman ini yang kemudian ia jadikan sebagai pekerjaan penggembala kambing-kambing milik penduduk Makkah.

Pengalaman Muhammad merupakan hasil terpaan pergulatannya dengan kehidupan masyarakat Jahiliyyah. Sejak usia 12 tahun Muhammad memiliki kecenderungan berbisnis. Ia pernah melakukan perjalanan ke Syam bersama pamannya, Abu Thalib. Ia juga mengunjungi pasar-pasar dan festival perdagangan, seperti di pasar Ukaz, Majinna, Dzul Majaz dan tempat lainnya. Gelar al-Amīn bagi dirinya yang waktu itu ia masih muda semakin menambah para pebisnis lain untuk membangun jaringan bersamanya, baik ketika ia menjadi karyawan Khadijah maupun menjadi suaminya.

Kesibukan sehari-harinya mengantarkan Muhammad menjadi pelaku bisnis yang profesional dengan mempertimbangkan etika bisnis yang diyakininya. Profesi ini ditekuni Muhammad hingga ia berusia 40 tahun, sejak ia resmi menjadi rasul. Hal ini juga mencerminkan bahwa segala perilaku dan perbuatannya yang dilakukan sebelumnya adalah bukan atas bimbingan wahyu, namun atas dasar pengalaman sosialnya dengan pertimbangan akal pikirannya.

Jika memerhatikan sejarah keberhasilan Muhammad dalam mengelola bisnis maka kuncinya adalah akhlak mulia (seperti tutur kata yang baik dan jujur). Namun apakah modal tersebut cukup dalam membekali seseorang 
dalam mengelola bisnis jika ia tidak memiliki latar belakang kuat dalam dunia bisnis. Faktor-faktor apa yang mendorong Muhammad menjadi pebisnis dan sukses dalam menggelutinya. Siapakah yang membimbingnya, sementara ia belum menjadi Nabi yang selalu menerima wahyu dan membimbingnya. Sementara al-Qur'an sebagai wahyu yang selalu membimbing Muhammad baru turun ketika ia berusia 40 tahun. Artinya selama 39 tahun, Muhammad belajar dari keluarga dan lingkungannya.

Kajian terhadap etika bisnis dalam agama sendiri sudah banyak dilakukan oleh beberapa kalangan intelektual Barat. Broel dan Chambel dalam bukunya Do Bussiness and Religion MIX sebagaiman dikutip oleh Sofyan Syafri $\mathrm{H}$ telah membahas agama dalam budaya Barat dan pengaruhnya dalam merumuskan etika bisnis. Demikian juga Thomas Golembiewski dalam bukunya Men Management and Morality Toward a New Organizational Ethics yang merumuskan nilai-nilai dasar bekerja menurut etika Yahudi dan Kristen. ${ }^{1}$

Dari kalangan Islam telah terbit pula buku Islamic Principles of Business Organizational and Management yang merupakan kumpulan makalah hasil seminar di Virginia Amerika pada tahun 1988. Diantara isi buku ini membahas etika bisnis dalam Islam dan pertanggungjawabannya dengan mendasarkan pada beberapa ayat al-Qur'an yang menerangkan tentang etika dalam mu'amalah. ${ }^{2}$

Selain kumpulan makalah di atas, terdapat juga beberapa buku tentang etika bisnis islami yang di tulis orang-orang Indonesia, antara lain karya M. Quraish Shihab, Muhammad, R. Lukman Fauroni, M. Suyanto, Faisal Badroen (dkk) dan mungkin beberapa buku lain yang belum penulis temukan. Muhammad Quraish Shihab dalam Jurnal Ulumul Qur'an membahas etika bisnis islami dengan judul "Etika Bisnis dalam Wawasan al-Qur'an". Kajian ini lebih memfokuskan pada tafsir ayat-ayat tentang bisnis, seperti larangan bisnis yang mengarah pada riba, dan fungsi uang dalam Islam. Pembahasan yang sama juga dimuat dalam Wawasan al-Qur'an dengan sub bahasan "Ekonomi". ${ }^{3}$ Kajian ini belum menyentuh bagaimana praktek bisnis Muhammad SAW dan beberapa hadits yang merupakan pesan Muhammad dalam bisnis.

\footnotetext{
${ }^{1}$ Sofyan Syafri Harahap, Akuntansi Islam, (Jakarta: Bumi Aksara, 1997), h. 230.

2 FR. Faridl (ed.), Islamic Principles of Business Organizational and Management, (New Delhi: Qazi Publeshers and Distributors, 1995), pp. 1-19.

${ }^{3}$ M. Quraish Shihab, "Etika Bisnis dalam Wawasan al-Qur'an," dalam Jurnal Ulumul Qur'an, No. 3/VII/1997. Lihat juga M. Quraish Shihab, Wawasan al-Qur'an; Tafsir Maudhu'I atas Pelbagai Persoalan Umat, (Bandung: Mizan, 1996), h. 402- 415.
} 
Tulisan Quraish Shihab tersebut mengilhami Lukman Fauroni untuk meneliti ayat-ayat al-Qur'an yang berbicara tentang etika bisnis. Judul buku Etika Bisnis dalam al-Qur'an yang ditulisnya secara detail menginventarisir dan mengupas ayat-ayat al-Qur'an yang terkait dengan prinsip-prinsip praktek bisnis islami. ${ }^{4}$ Karena fokusnya adalah al-Qur'an, maka Lukman tidak menyinggung praktek bisnis Muhammad dan beberapa haditsnya. Terkait dengan telaah pustaka ini, pokok bahasan buku tersebut membahas jenis-jenis bisnis dan etika bisnis yang meliputi kesatuan, kesetimbangan, kehendak bebas, pertanggungjawaban, dan kebajikan serta kejujuran, yang didasarkan pada ayatayat al-Qur'an.

Muhammad (Dosen STIS Yogyakarta dan Pascasarjana di beberapa tempat) pada bab pendahuluan bukunya menyinggung bisnis Muhammad SAW setelah menikah dengan Khadijah. Kajian empat setengah halaman ini hanya mendeskripsikan kunjungan Muhammad ke beberapa negara dan bentuk transaksi dalam Islam. ${ }^{5}$ Kajian ini belum sampai pada bagaimana etika bisnis yang dilakukan Muhammad dalam menjalankan bisnisnya, khususnya sebelum masa kewahyuan. Tercatat dalam sejarah, ketika Muhammad dalam usia 12 tahun ia sudah diajak untuk bisnis ke Syiria dan banyak pesan moral dalam menjalankan bisnis yang dirangkum dalam hadits.

Terkait dengan kajian ini, M. Suyanto juga menulis buku dengan judul Muhammad Business Strategy and Ethics. Dalam buku ini ia mengkaji tentang etika bisnis Muhammad. Kajiannya terfokus pada etika mencari harta dan membelanjakannya, strategi bisnis dan tujuannya, serta perilaku bisnis yang dianjurkan dan dilarang. Meskipun sub judul bab ini mencerminkan etika bisnis Muhammad, namun kajiannya lebih menekankan pada teks-teks alQur'an, seperti etika bisnis harus berlandaskan iman kepada Allah dan rasulNya, strategi bisnis harus sesuai dengan jalan Allah, dan tujuan bisnis untuk memperoleh keuntungan besar. Demikian juga etika bahasan tentang etika bisnis terfokus pada kompilasi ayat-ayat al-Qur'an dan hadits. Dari paparan singkat ini tanpak bahwa kajiannya menekankan pada pesan-pesan (nabi) Muhammad setelah menjadi Nabi (ba'd al bi'tsah). ${ }^{6}$

${ }^{4}$ R. Lukman Fauroni, Etika Bisnis dalam al-Qur'an, (Yogyakarta: Pustaka Pesantren-LKiS, 2006), h. 115-156.

${ }^{5}$ Muhammad, Etika Bisnis Islami, (Yogyakarta: UPP AMP YKPN, 2004), h. xv-xviii.

${ }^{6}$ M. Suyanto, Muhammad Business Strategy and Ethics, (Yogyakarta: Andi Offset, 2008). Penjelasan lebih lengkap lihat buku ini h. 169-218. 
Buku lain yang membahas etika bisnis islami adalah kumpulan tulisan yang disarikan oleh Faisal Badroen (editor) dengan judul Etika Bisnis dalam Islam. Buku ini menfokuskan pada kajian komparatif antara etika bisnis yang dikembangkan di Barat dan Islam. ${ }^{7}$ Secara konseptual Barat, prinsip-prinsip etika dalam bisnis mengacu-paling tidak pada empat hal-, pertama, mengandung unsur utilitas (manfaat); kedua, terdapat unsur hak dan kewajiban; ketiga, mengandung keadilan dan kejujuran; dan keempat mengandung rasa melindungi. Keempat hal tersebut menjadi guidance bagi Barat dalam menentukan standarisasi etika dalam berbisnis, khususnya yang berkenaan dengan pengambilan keputusan (ethical dilemmas). ${ }^{8}$

Dari beberapa tulisan yang telah disebutkan tampak tampak penggalian etika bisnis lebih banyak berasal dari al-Qur'an dan al-Hadits. Tentang sumber al-Qur'annya telah banyak dikaji oleh banyak penulis. Sedangkan pada aspek al-Hadits belum diungkap, khususnya yang terkait dengan etika bisnis yang dilakukan Muhammad SAW sebelum masa kenabian. Dalam hal inilah penulis mencoba melakukan penelusuran.

\section{B. Etika Bisnis dalam Studi Islam}

Kata etika berasal dari kata ethos dalam bahasa Yunani yang berarti kebiasaan (custom). Dalam kamus Webster etika adalah the distinguishing character, sentiment, moral nature, or guiding beliefs of a person, group, or institution (karakter istimewa, sentimen, tabiat moral, atau keyakinan yang membimbing seseorang, kelompok atau institusi). ${ }^{9}$ Pengertian yang lebih tegas makna etika adalah the systematic study of the nature of value concepts, good, bad, ought, right, wrong, etc. And of the general principles which justify us in applying them to anything; also called moral philosophy (etika merupakan studi sistematis tentang tabiat konsep nilai, baik, buruk, harus, benar, salah, dan lain sebagainya dan prinsip-prinsip umum yang membenarkan kita untuk mengaplikasikannya atas apa saja). ${ }^{10}$

\footnotetext{
${ }^{7}$ Drs. Faisal Badroen (ed.), Etika Bisnis dalam Islam, (Jakarta: Prenada Media Group, 2006), bab II dan bab IV. h. 41-43.

${ }^{8}$ Lihat juga Amirullah dan Imam Harjanto, Pengantar Bisnis, (Yogyakarta: Graha Ilmu, 2005),

${ }^{9}$ Webster's New CollegiatemDictionary, (USA: G. dan C.Merriam Company), p. 393.

${ }^{10}$ Drs. Achmad Charris Zubair, Kuliah Etika, (Jakarta: Rajawali Press, 1995), h. 13.
} 
Pengertian di atas semakna dengan kata moral. Kata ini berasal dari bahasa Latin mos, (jamaknya: mores) yang artinya adat istiadat atau kebiasaan. Yang dimaksud adat istiadat ini adalah kebiasaan yang dilakukan oleh individu maupun masyarakat. Dengan demikian maka secara terminologi istilah antara etika dan moralitas memiliki pengertian yang sama.

Dalam studi islam istilah di atas senada dengan al-khuluq. Dalam alQur'an kata ini hanya ditemukan dalam bentuk tunggal (al-khuluq) dalam surat al-Qalam ayat 4 sebagai nilai konsiderans atas pengangkatan Muhammad sebagai Rasul. (Sesungguhnya engkau Muhammad berada di atas budi pekerti yang agung). Al-khuluq artinya innate peculiarity, natural disposition, character, temper, nature. ${ }^{11}$ Dengan demikian maka akhlak adalah perilaku seseorang yangberkaitan dengan baik dan buruk, dan setiap manusia memiliki dua potensi di atas. Hanya saja dalam Islam potensi baik lebih dulu menghiasi diri manusia daripada potensi untuk berbuat kejahatan. ${ }^{12}$ Dengan demikian maka etika bisnis yang dimaksud dalam tulisan ini adalah seperangkat prinsip-prinsip etika yang membedakan yang baik dan yang buruk, harus, benar, salah, dan lain sebagainya dan prinsip-prinsip umum yang membenarkan seseorang untuk mengaplikasikannya atas apa saja dalam dunia bisnis.

\section{Kehidupan Muhammad sebelum Masa Kenabian}

Yang dimaksud Muhammad dalam tulisan ini adalah Muhammad bin Abdullah bin Abd1ul Muthalib bin Hasyim bin Abdi Manaf bin Qushay bin Kilab bin Murrah bin Kinanah bin Khuzaimah bin Mudrikah bin Ilyas bin Mudhar bin Nizar bin Ma'ad bin Adnan. Ia lahir pada hari Senin tanggal 12 Rabi'ul Awwal tahun Gajah bertepatan dengan tanggal 20 April 571 M. Ia meninggal pada usia 63 tahun, tepatnya pada hari Senin tanggal 13 Rabiul Awal 11 Pada tahun $11 \mathrm{H}$, tanggal 12 Rabi'ul Awwal 11 atau 8 Juni 632.

Berdasarkan peran dan tugas (nabi) Muhammad, masa kehidupannya dapat diklasifikasikan menjadi dua periode, yaitu masa sebelum kenabian atau qab al-bi'tsah dan masa kenabian, setelah ia diangkat menjadi Rasul atau disebut masa ba'd al-bi'tsah. Masa pra kenabian terjadi sejak Muhammad di-

\footnotetext{
${ }^{11}$ Hans Wehr, A Dictionary of Modern Written Arabic, (London: McDonald \& Evans Ltd, 1980), p. 258.

${ }^{12}$ M. Quraish Shihab, Wawasan al-Qur'an, (Bandung: Mizan, 1996), h. 254.
} 
lahirkan pada $571 \mathrm{M}$ hingga $611 \mathrm{M}$. Masa ini berlangsung selama 39 tahun dan saat itu Muhammad berusia 39 tahun. Pada usia 40 tahun, Muhammad telah menerima wahyu. Sejak itu kehidupannya atas bimbingan ayat-ayat alQur'an yang diturunkan melalui malaikat Jibril.

Kehidupan Muhammad sebelum kenabian merupakan sesuatu yang natural. Ia hidup dan bergaual layaknya masyarakat pada waktu itu. Namun selama itu pula, Muhammad mampu belajar dari lingkungannya hingga ia menjadi orang besar. Gelar al-Amin ia peroleh semasa dewasa. Pengalaman bisnisnya ia peroleh dari realitas sosial, ketika ia mengunjungi beberapa pasar dan festival perdagangan, serta kunjungan ke negara Syam, sebuah negara yang menjadi sentral perdagangan dunia pada saat itu.

Untuk melakukan kajian ini memang tidak mudah meskipun bersifat library research sehingga harus ditemukan catatan sejarah perihal bisnis Nabi baik dari sumber primer maupun sekunder. ${ }^{13}$ Sedangkan teknik pengumpulan dilakukan dengan: (1) klasifikasi sumber yang berhubungan dengan sejarah; (2) pencarian dimana tempat terdapatnya sejarah; (3) menyusun data secara sistematis, dan (4) mengritik sumber bahan yang ada. ${ }^{14}$ Karena itulah pendekatan yang akan digunakan adalah pendekatan sejarah dengan merekonstruksi masa lalu secara sistematis dan objektif dengan mengumpulkan, mengevaluasi, menguji dan mensintesiskan bukti-bukti untuk menegakkan fakta dan memperoleh kesimpulan secara tepat. ${ }^{15}$

Untuk merekonstruksi sejarah ini, setidaknya ada empat langkah yang akan ditempuh, yakni heuristik, kritik, interpretasi dan historiografi ${ }^{16}$. Adapun analisisnya menggunakan analisis kualitatif dengan cara kritik eksternal dan kritik internal. L.R. Gay sebagaimana dikutip oleh Consuelo, kritik eksternal ini dilakukan terhadap sumber asli yang memiliki integritas tekstual. Setelah mengetahui dengan pasti keaslian bahan-bahan kemudian dilakukan kritik internal, yaitu kritik terhadap teks itu sendiri. ${ }^{17}$

${ }^{13}$ Marzuki, Drs., Metodologi Riset, (Yogyakarta: BPFE-UII, 2000), h. 56-57.

${ }^{14}$ Consuello G. Sevilla, dkk., Pengantar Metode Penelitian, (Yogyakarta: UII Press, 1993), h. 49-54.

${ }^{15}$ Lihat Stephen Isaac dan William B. Michael, Handbook in Research and Evaluation, California: EdTs Publisher, 1981, p. 44; Moh. Nazir, Ph.D., Metode Penelitian, (Bogor: Ghalia Indonesia, 2005), h. 48.

${ }^{16}$ Lihat Hariyono, Mempelajari Sejarah Secara Efektif; (Jakarta: Pustaka Jaya, 1995), h. 109.

${ }^{17}$ Consuello G. Sevilla, dkk, Pengantar Metode Penelitian, h. 59 


\section{Faktor-faktor Yang Mendorong Muhammad Menjadi Pebisnis}

\section{Faktor Geografis Arab}

Sejarawan Muslim membagi penduduk Arab menjadi tiga kelompok, yaitu al-Arab al-Badi'ah (Arab kuno), 'Arab al-Arabiyah (Arab pribumi), dan 'Arab alMustaribah (Arab pendatang). Keberadaan komunitas Arab kuno ini sudah tidak diketahui sejarahnya. Sedangkan orang Arab pribumi adalah turunan dari Khatan yang lebih populer dengan Arab Yaman, dan Arab pendatang adalah turunan dari nenek moyang Nabi Ismail yang datang berdiam di Hejaz, Tahama, Nejad, Palmerah, dan lain-lain yang dikenal sebagai penduduk Arab Utara. Dari segi tempat mereka terbagi menjadi dua kelompok, yaitu ahl al-Hadharah (penduduk kota) dan ahl al-Badiyah (penduduk gurun pasir). Kondisi geografis yang berbeda-beda ini berpengaruh pada perbedaan pranata sosial, tata cara kehidupan, profesi mencari nafkah (ekonomi), dan peradaban..$^{18}$

Karena faktor geografis, perekonomian yang dijalankan oleh bangsa Arab sebelum Islam amat sangat sederhana dan terbatas. Mayoritas aktivitas ekonomi penduduk Arab adalah menggembala dan berternak binatang. Mereka yang bekerja dalam dunia pertanian atau perdagangan juga tidak bisa lepas dari peternakan. Hal ini disebabkan para petani membutuhkan hewanhewan untuk mendukung aktivitasnya di pertanian. Demikian juga pedagang membutuhkan binatang untuk mengangkut dagangannya. Wajar jika persengketaan antara warga berkutat pada masalah peternakan. K. Hitti sebagaimana dikutip oleh Abdul Karim bahwa konflik antara penduduk Arab seputar pada persengkataan hewan ternak, padang rumput dan mata air. ${ }^{19}$

Aktivitas ekonomi bangsa Arab meliputi tiga bidang, yaitu perdagangan, pertanian dan industri. Perdagangan dilakukan oleh orang-orang yang tinggal daerah perkotaan. Aktivitas ini dijalankan terutama di Makkah sebagai kawasan yang tandus. Makkah adalah pusat kota dimana orang sering berziarah dan berkumpul di ka'bah. Di daerah ini juga sering ada pasar musiman sebagai tempat perdagangan. Letak Makkah sangat strategis karena ia meng-

\footnotetext{
${ }^{18}$ M. Abdul Karim, History of the Muslim Thought and Civillization, terj. Tim Pustaka Book Publisher, Sejarah Pemikiran dan Peradaban, (Yogyakarta: Pustaka Book Publisher, 2007), h. 50.

${ }^{19}$ Ibid., h. 52-53.
} 
hubungkan lalulintas perekonomian, yaitu Syam (Yordania, Palestina, Libya), Yaman dan Habasyah (Ethiopia).20

Aktivitas pertanian dilakukan bangsa Arab di daerah-daerah yang subur seperti Yaman, Thaif, daerah utara dan sebagian lahan pertanian di Hijaz. Pada umumnya kegiatan pertanian ini di desa daerah-daerah tersebut. Madinah adalah salah satu kota yang memiliki kesuburan tanah dan irigasi bagus, sehingga daerah ini merupakan penghasil kurma, gandum dan buah-buahan..$^{21}$ Sedangkan kegiatan industri hanya dilakukan sebagain kecil bangsa Arab. Profesi ini dilakukan oleh para budak dan orang Yahudi. Profesi yang cukup menonjol adalah tukang besi, tukang kayu, pembuatan senjata, dan pertenunan.

Muhammad ketika masa kecilnya menjadi penggembala binatang dengan penghasilan yang tidak banyak. Pekerjaan ini ia lakukan dengan terpaksa hingga ia di bawah asuhan Abu Thalib. Muhammad sadar bahwa menggembala bukan profesinya. Pengalaman menggembala ia peroleh ketika bersama anak-anak Halimah di kampung Banu Sa'ad. Setelah usia 4 tahun ia dikembalikan kepada ibunya (Aminah) dan menjadi penggembala untuk memenuhi kehidupannya.

Adapun orang tuanya (Abdullah) dan pamannya adalah seorang pedagang. Ia dibesarkan dalam wilayah perdagangan. Apa yang ia lihat dan rasakan di Makkah menuntut dirinya untuk menjadi pedagang. Kesempatan untuk menjadi pedagang muncul ketika ia di bawah asuhan Abu Thalib yang profesinya sebagai pedagang. Pada masa asuhannya, Muhammad sering berkunjung dan berjualan di pusat-pusat keramaian, seperti pasar Ukaz, Majinna, Dzul Majaz, Basra, dan lain-lain.

Keinginan turut serta dalam kafilah berdagang selalau ditolak Abu Thalib dengan alasan keselamatan Muhammad. Setelah Abu Thalib merasa bahwa keinginan Muhammad untuk turut serta dalam rombongan kafilah berdagang semakin kuat, Abu Thalib menginjinkannya. Saat itulah Muhammad dapat menyaksikan bagaimana menempuh perjalanan jauh dan transaksi ekonomi dilangsungkan. Dengan demikian maka pembacaan Muham-

${ }^{20}$ Dr. Jaribah bin Ahmad al-Haritsi, al-Fiqh al-Iqtișādi li Amīr al-Mu'minīn, terj. H. Asmuni Sholihan Z, Lc., Fiqih Ekonomi Umar bin al Khathab, (Jakarta: Califa, 2006), h. 32.

${ }^{21}$ Menurut catatan Ibnu Hajar dalam Fath al-Bari, Jil. 4 h. 503-504, Madinah pernah mengalami masa paceklik dan ini terjadi sebelum datangnya Islam. Pada musim paceklik ini para penduduknya memakan daun-daunan. 
mad terhadap kondisi geografis Makkah menjadi motivator bagi dirinya untuk menekuni bisnis, bukan bertani atau menjadi penggembala.

\section{Faktor Ekonomi}

Abdullah ibn Abdul Muthalib, orang tua Muhammad meninggal dalam usia muda, yakni tiga bulan setelah hari pernikahannya dengan Aminah. Ia meninggalkan sedikit warisan berupa lima ekor unta, beberapa ekor kambing dan seorang budak perempuan bernama Ummu Aiman.22 Unta dan kambing yang jumlahnya hanya sedikit tersebut habis digunakan untuk biaya persalinan dan perawatan Muhammad. Sejak lahir, Muhammad disusui ibunyah selama tiga hari. Kemudian ia disusui oleh Suwaibah (budak Abu Lahab) selama empat bulan. Selanjutnya ia disusui Halimah bint Abi Zuwayb dari banu Sa'id ibn Bakr, seorang ibu dari suku Badui desa Banu Sa'ad yang berprofesi sebagai pengasuh dan ibu menyusui. Namun Halimah tidak menerima upah, karena Aminah adalah keluarga miskin dan tidak mampu membayarnya. Untuk mendeskripsikan bagaimana faktor ekonomi menjadi pendorong Muhammad sebagai pebisnis, pada tabel 1 menunjukkan beberapa orang yang mengasuh Muhammad sejak dilahirkan.

Tabel 1.

Para Pengasuh Muhammad Sejak Lahir Hingga Menikah

\begin{tabular}{|l|c|c|c|}
\hline \multicolumn{1}{|c|}{ Nama/Status } & Lama Mengasuh & Tempat & Status Ekonomi \\
\hline $\begin{array}{l}\text { Halimah (Pemelihara Bayi } \\
\text { Profesional) }\end{array}$ & 4 tahun (571-575 M) & Kampung Sa'ad & Miskin \\
\hline Aminah (Ibu Kandung) & 2 tahun (575-577 M) & Kota Makkah & Miskin \\
\hline Abdul Muthalib (Kakek) & 2 tahun (577-579 M) & Kota Makkah & Kaya \\
\hline Abu Thalib (Paman) & 15 tahun (579-594 M) & Kota Makkah & Miskin \\
\hline
\end{tabular}

Sumber: Dikembangkan untuk penelitian.

Pertama, Muhammad diasuh oleh Halimah di kampung Sa’ad. Kampung Sa'ad adalah tempat dimana banyak Ibu-ibu yang memiliki profesi menyusui sekaligus sebagai ibu asuh. Atas jasanya mereka akan menerima biaya pe-

${ }^{22}$ KH. Moenawar Cholil, Kelengkapan Tarikh Nabi Muhammad, Jil. 1, (Jakarta: Gema Insani Press, 2006), h. 81. Ummu Aiman inilah yang di kemudian hari merawat (melayani) Muhammad dan Aminah. 
rawatan bayi selama diasuhnya dan jasa atas pekerjaannya. Kampung Sa'ad ini berjarak $60 \mathrm{KM}$ dari Makkah.

Suatu waktu ibu-ibu asuh ini berombongan menuju Makkah untuk mencari anak asuh. Salah satu rombongan tersebut adalah Halimah, sebuah klan dari suku Hawazin. Beberapa kawan Halimah telah mendapatkan bayi asuh, sementara Halimah belum mendapatkan. Ia berkunjung ke rumah Siti Aminah karena diketahui ia memiliki bayi yang baru saja dilahirkan. Setelah melihat Muhammad, Halimah tertarik untuk merawatnya. Namun ia ragu karena bayi yang akan diasuhnya adalah anak yatim dan keluarga miskin. Akhirnya Halimah minta pertimbangan suaminya (Haris). Ia menceritakan kepada suaminya tentang apa yang dialaminya. Ia gagal memperoleh bayi, namun ada seorang bayi yang memiliki daya tarik dan Halimah ingin untuk mengasuhnya meskipun tanpa upah. Setelah memperoleh pertimbangan dan ijin dari suaminya, Halimah kembali menemui Aminah dan akhirnya Muhammad diserahkan kepada Halimah. Aminah merasa senang melepas Muhammad meskipun berat melepasnya. Aminah hanya berharap agar anaknya menjadi orang yang memiliki kemandirian sebagaimana anak-anak lain yang diasuh oleh orang-orang Badui. Halimah berharap dengan mengasuh Muhammad ia akan memperoleh berkah dari Tuhan.23

Halimah adalah keluarga miskin. Ia hanya memiliki beberapa kambing sebagai sumber penghidupannya. Kehadiran Muhammad dalam keluarganya menambah biaya kebutuhan hidupnya sekaligus membawa berkah. Kambing yang dirawatnya semakin bertambah dan susunya melimpah, tanaman Halimah juga menjadi subur dan memperoleh keuntungan yang berlipat. ${ }^{24}$ Namun Halimah merasa ada sesuatu yang aneh pada diri Muhammad sehingga ia berhasrat untuk memeliharanya. Selama masa asuhan Halimah,

\footnotetext{
${ }^{23}$ Muhammad bin Yasar menggambarkan keberhakan Halimah yang diperoleh melalui wasilah pemeliharaan Muhammad cukup banyak. Ketika Halimah membawa Muhammad menuju kampung Sa'ad, dalam perjalanan Halimah menyusuinya. Ia merasa aneh karena air susunya mengalir deras keluar. Binatang-binatang ternak milik Halimah, seperti onta dan kambing juga air susunya melimpah. Keluarga mereka meminum susu, termasuk Muhammad. Bahkan air susu yang diperolehnya surplus. Demikian juga binatang ternak tersebut berkembang dengan pesat. Rizki yang diperoleh Halimah terdengar oleh masyarakat, sehingga mereka para penduduk meminta agar para penggembalanya mengikuti hewan-hewan ternah Halimah dimana hewan ternak tersebut digembala. Dengan cara ini penduduk berharap agar air susu hewan ternaknya melimpah. Lihat Muhammad bin Yasar ibn Isaac, Sirah Ibn Ishaq, (Surakarta: Muhammadiyah University Press, 2002), h. 105.
}

${ }^{24}$ H. Rus'an, Lintasan Sejarah Islam di Zaman Rasulullah SAW,(Semarang: Wicaksana, 1981), h. 21. 
Muhammad memiliki keistemewaan-keistimewaan dibanding dengan bayi pada umumnya. Pada usia 5 bulan Muhammad sudah mampu berjalan dan pada usia 9 bulan ia sudah berbicara. Pada usia 2 tahun ia sudah bisa dilepas bersama-sama anak Halimah untuk menggembala kambing yang dimilikinya.

Muhammad diasuh oleh Halimah sebanyak dua kali selama empat tahun. Tahap pertama ketika beberapa saat setelah ia dilahirkan hingga berusia dua tahun. Tahap kedua, ketika Makkah dilanda wabah penyakit, Halimah mendatangi Aminah untuk merawatnya. Asuhan kedua ini terjadi selama dua tahun. Selama di bawah asuhan Halimah, Muhammad hidup dalam serba kekurangan mengingat keluarga Halimah adalah keluarga miskin.

Kedua, Muhammad dipangkuan ibunya (Aminah). Setelah Muhammad diasuh selama 4 tahun, ia dikembalikan kepada ibunya. Dengan senang hati Aminah menerimanya karena ia sangat rindu kepadanya. Ia hidup bersama ibunya selama dua tahun (575-577 M). Selama bersama ibunya Muhammad Muhammad membantu tetangganya menggembalakan kambing untuk memperoleh upah. Meskipun upahnya kecil Muhammad dengan senang hati melakukannya. Hasil jerih payahnya diberikan kepada ibunya untuk menambah biaya hidup, karena Aminah adalah seorang janda miskin.

Pengalaman menggembala diperoleh Muhammad sewaktu diasuh oleh Halimah. Pada usia dua tahun ia sudah bisa berjalan dan berlari. Ia sudah bisa dilepas untuk menggembala kambing bersama anak-anak Halimah. Memang Muhammad memiliki banyak kelebihan dibanding dengan anak seusianya. Ia tidak malu menjadi penggembala karena tuntutan hidup. Satu-satunya kegiatan yang bisa dilakukan adalah membantu ibunya meringankan biaya hidup dengan cara menggembala. Ia belum bisa bekerja selain menggembala karena usianya masih kecil.

Ketiga, Muhammad diasuh oleh Abdul Muthalib. Sejak ibunya meninggal pada tahun $577 \mathrm{M}$, muhammad yang saat itu berusia 6 tahun diajak pindah tinggal bersama kakeknya, Abdul Muthalib. Bersama kakeknya kehidupannya lebih baik dibanding bersama ibunya. Abdul Muthalib adalah orang kaya dan memiliki pengaruh besar terhadap masyarakat suku Quraisy. Meskipun ia hidup di tengah-tengah keluarga yang kaya raya, Muhammad masih bekerja sebagai penggembala. Ia tidak merasa malu karena pekerjaannya adalah halal dan mulia, meski upahnya tidak banyak.

Pekerjaan menjadi penggembala merupakan pekerjaan yang mulia. Sejarah nabi-nabi terdahulu juga pernah menjadi penggembala. Hal ini di- 
tegaskan oleh Muhammad setelah diangkat menjadi nabi, ia berkata: "Nabi Musa diutus dan dia adalah seorang penggembala kambing, dan nabi Daud diutus dan dia seorang penggembala kambing dan aku diutus dan aku juga penggembala kambing keluargaku di kampung Jiyad..$^{25}$

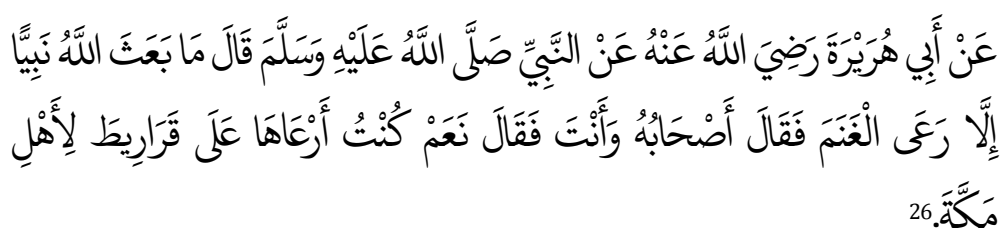

Abi Hurairah ra., (meriwayatkan) dari Nabi (Muhammad) SAW berkata: "Allah tidak mengutus seorang nabi melainkan dia pernah menggembala kambing." Sahabat Nabi berkata: "Engkau (juga sebagai penggembala kambing)." Nabi menjawab: "Ya, aku pernah menjadi penggembala kambing milik orang Makkah."

Kehidupan ekonomi Muhammad bersama kakeknya yang agak lebih baik. Ia merasa aman dan terjamin makannya. Namun kondisi ini tidak berlangsung lama, karena Abdul Muthalib meninggal dunia pada tahun $579 \mathrm{M}$.

Keempat, Muhammad diasuh oleh pamannya. Pemeliharaan Muhammad oleh Abu Thalib berdasarkan wasiat Abdul Muthalib ketika ia sedang sakit. Abu Thalib adalah salah satu anak Abdul Muthalib yang kurang mampu (miskin). Mengapa Abdul Muthalib tidak menyerahkan pemeliharaan Muhammad kepada anak tertuanya (Haris) atau kepada Abbas yang kaya raya. Andaikan Muhammad dipelihara oleh Abbas, maka Muhammad akan hidup sejahtera. Sikap Abdul Muthalib yang menyerahkan pemeliharaan Muhammad kepada Abu Thalib dengan pertimbangan Abu Thalib adalah orang yang disegani masyarakat Quraisy karena memiliki akhlak yang baik. Bahkan menurut satu riwayat, pemeliharaan Abu Thalib kepada Muhammad melebihi anaknya sendiri. Kemanapun Abu Thalib pergi, Muhammad selalu bersamanya.

${ }^{25}$ Hadits ini diriwayatkan oleh al-Nasa'i dari Nashra bin Hazm.

${ }^{26}$ Hadits Bukhari No. 2102. Ini merupakan hadits sharîf marfü'. Menurut sebagian riwayat, keinginan menggembala kambing bukan hakikat keinginan Muhammad, melainkan kehendak Allah karena ia adalah calon pemimpin umat. Pemimpin umat-umat terdahulu adalah sebagian mereka pernah menjadi penggembala kambing. 
Ketika Abu Thalib bersiap-siap untuk berangkat berniaga ke Syam, Muhammad yang saat itu berusia 12 tahun menyusulnya agar diperkenankan ikut bersama kafilah dagang. Semula Muhammad akan ditinggal di rumah karena Abu Thalib khawatir atas keselamatan dan kesehatan Muhammad untuk menempuh perjalanan jauh. Karena kasih sayangnya, keinginan Muhammad dikabulkan oleh pamannya. Kepergian Muhammad ke Syam untuk yang pertama kali ini terjadi pada tahun $583 \mathrm{M}$.

Negeri Syam merupakan salah satu negeri yang terpenting bagi daerah Semenanjung Arabia. Negeri ini terkenal subur dan kaya raya, sehingga terkenal ia menjadi salah satu tujuan bisnis. Bahkan sebagain lain para pendatang menetap dan menggembala kambing serta mengembangkan bisnisnya di Syam. Hubungan antara Syam dan Jazirah Arab ini sudah terbina sejak lama dan tidak pernah terputus dari waktu ke waktu, yang secara umum terfokus dalam bisnis ekspor impor bahan makanan dan hasil industri. ${ }^{27}$

Perniagaan Abu Thalib bersama keponakannya di Syam ini tidak memperoleh untung banyak karena mereka harus segera pulang ke Makkah sesuai pesan pendeta Bakhira. Pesan ini diperoleh ketika perjumpaannya dengan pendeta Bakhira di Basra dalam perjalanan Makkah menuju Syam. Bakhira menjelaskan kepada Abu Thalib bahwa anak yang bersamanya memiliki ciriciri kenabian dan kelak akan dimusuhi bangsanya sebagaimana termaktub dalam kitab injil..$^{28}$ Sejak itu Abu Thalib merasa gelisah dan khawatir, sehingga ia tidak lama tinggal berdagang di Syam. Dengan keuntungan yang cukup Abu Thalib dan Muhammad pulang. Abu Thalib tidak kecewa meskipun tidak membawa untung banyak, asal Muhammad selamat sampai di Makkah.

Untuk memenuhi kebutuhan sehari-harinya serta membantu ekonomi Abu Thalib, Muhammad bekerja sebagai pegawai Khadijah, seorang janda kaya raya. Pamannya memperkenalkan Muhammad kepada Khadijah dan melamarkannya menjadi karyawannya. Khadijah tidak keberatan, karena Muhammad sudah cukup terkenal sebagai sosok pemuda yang berakhlak mulia dan jujur.

\footnotetext{
${ }^{27}$ M. Suyanto, Muhammad Business Strategy and Ethics, h. 92.

${ }_{28}$ Menurut Ibnu Ishaq, sebagaimana dikutip M. Suyanto, Pendeta Bakhira menanyakan beberapa hal kepada Muhammad, seperti bagaimana ketika hendak tidur, kegiatan sehari-harinya, dan lain sebaginya. Bakhira juga memeriksa memeriksa punggung Muhammad untuk membuktikan tanda-tanda kenabian pada kedua pundaknya. Apa yang disaksikan Bakhira sesuai dengan kitab sucinya, bahwa Muhammad adalah calon Nabi.
} 
Gelar al Amin baginya sudah tersebar di pelosok Makkah. Sejak itu Muhammad bekerja sebagai pekerja Khadijah. Dengan demikian dapat disimpulkan bahwa kondisi ekonomi lemah keluarga muhammad menjadi salah satu faktor yang mendorong Muhammad menjadi seorang pedagang.

\section{Faktor Keluarga}

Ayah Muhammad bernama Abdullah ibn Abdul Muthalib,, ${ }^{29}$ cucu Hisyam, tokoh pendiri klan Hasyimiyah pada suku Quraisy. Jika dirunut dari kakeknya, Muhammad berasal dari keluarga yang kaya raya. Abdul Muthalib adalah orang yang kaya raya. Disamping dikenal sebagai orang yang kaya raya, ia memiliki jabatan tinggi sebagai pembesar kaum Quraisy. Ketika terjadi perampokan binatang ternak oleh tentara Abrahah, Abdul Muthalib menemui Abrahah di perkemahan. Abrahah turun dari tahtanya dan memjabat tangan serta mempersilahkan duduk disebelahnya. Kebesaran Abdul Muthalib diakui oleh Abrahah sehingga ia menghormatinya. Abdul Muthalib bernegosiasi agar binatangbinatang ternak Kebesarannya membuat Abrahah akan menyerang Ka'bah, Abdul Muthalib berada di depan untuk melakukan negosiasi kepada Abrahah.

Meskipun leluhurnya adalah orang kaya, Muhammad tidak merasa bangga atas kekayaannya. Muhammad hanya merasa aman jika bersama kakeknya karena ia dikenal sebagai orang yang berpengaruh di kalangan Quraisy. Ketika kakeknya meninggal, ia diasuh oleh pamannya, Abu Thalib. Pengasuhan Abu Thalib berdasarkan wasiat yang dibuatnya. Abdul Muthalib sadar bahwa Abu Thalib mampu memelihara Muhammad meskipun ekonominya lemah dibanding saudara-saudaranya seperti Harits. Pilihan Abdul Muthalib berdasarkan kepribadiannya yang memiliki sikap terpuji dan disegani orang-orang Quraisy. Pemeliharaan Abu Thalib sejak Muhammad berusia 8 (delapan) tahun. Selama dalam perawatan dan asuhan Abu Thalib,

\footnotetext{
${ }^{29}$ Nama asli Abdul Muthalib adalah Syaibah, lahir dan dibesarkan di Madinah. Ibunya adalah Salma bint Amr dari keluarga Najjar dari suku Kharraj di Madinah. Setelah Hasyim meninggal, pamannya yang bernama Muthalib membawanya ke Makkah, sehingga ia dijuluki "Abdul Muthalib" (budak al-Muthalib) karena saat tiba di Madinah ia duduk di atas punggung unta sang paman, sehingga ia disangka budak sang paman. Di Makkah ini Abdul Muthalib menjadi kaya dan terkenal di kalangan Quraisy. Karena sejak pertumpahan darah antara Abd al-Dar melawan Abd al-Manaf tidak ada pemimpin yang memiliki pengaruh dan popularitas besar. Kevakuman pemimpin tergantikan oleh Abdul Muthalib. Ia menjadi kaya setelah berhasil menggali lokasi air zamzam dipendam oleh suku jurhum yang mendiami Makkah sebelum Quraisy. Upaya penggalian ini diilhami oleh mimpi Abdul Muthalib ketika ia tidur di Hijir Ismail. Dari air zamzam ini Abdul Muthalib melakukan distribusi air kepada masyarakat sekitar dan para jamah haji. Setelah ia meninggal, penguasaan air zamzam tersebut diserahkan kepada anaknya yang bernama Abbas.
} 
Muhammad memiliki banyak pengalaman, khususnya yang mendorong dirinya untuk menjadi pedagang (pebisnis).

Muhammad sering diajak Abu Thalib ke pekan-pekan perdagangan, seperti di pasar Ukaz, Majinnah, dan Dzul Majaz. Pasar Ukaz berada di al-Athdia yang terletak antara Thaif dengan Nakhla dan antara Majinnah dengan Dzul Majaz. Pasar Ukaz yang digelar setiap tanggal 1-20 Dzul Qa'dah dikenal sebagai pasar kuna yang terkenal sejak tahun 500 sebelum Masehi di semenajung Arabia. ${ }^{30}$ Nama tersebut diambil dari dari aktivitas yang dikerjakan oleh masyarakat sekitar. Di pasar tersebut dipamerkan hasil kreativitas manusia (pidato dan penyajian syair-syair) dan sumber alam. Pasar ini memiliki hubungan perdagangan yang luas, sehingga banyak dikunjungi para pendatang, seperti suku Quraisy, Hawazin, Ghatafan, Aslam, Ahabish, Adl, alDish, al-Haya dan al-Mustaliq. Orang yang beraktivitas di pasar Ukaz ini memperoleh jaminan dari masyarakat. Lokasi dan waktu pembukaan pasar disesuaikan dengan musim haji dimana pada bulan tersebut disepakati tidak ada tindak kekerasan, angkat senjata dan perang. Barang siapa yang melanggar kesepakatan tersebut akan memperoleh hukuman. Di pasar ini Muhammad melihat traksaksi perdagangan dilaksanakan. Ia juga mendengarkan lomba pidato dan syair-syair yang mengunggulkan suku masing-masing. Berdasarkan catatan sejarah, Muhammad mengunjungi pasar tersebut sebanyak tujuh kali. Sebagian diantaranya, kunjungannya ke Ukaz untuk menyampaikan dakwah setelah ia diangkat menjadi Nabi.

Di samping pasar Ukaz, Muhammad juga mengunjungi pasar Majinnah dan Dzul Majaz yang berada diantara Makkah dan Thaif. Pasar Majinnah digelar setelah pasar Ukaz. Jika pasar Ukaz digelar selama 20 hari hingga tanggal 20 Dzul Qa'dah, pasar Majinnah digelar setelah pasar Ukaz selesai hingga tanggal 30 Dzulqa'dah. Setelah pasar ini selesai, pekan perdagangan dilaksanakan di pasar Dzul Majaz mulai tanggal 1-7 Dzul Hijjah. Di kedua pasar tersebut dijual berbagai kebutuhan hidup, seperti gandum, kurma dan lain-lain. Pasar ini diramaikan pula dengan arena pertandingan pembacaan syair-syair Arab. Kunjungan Muhammad beberapa kali di pasar-pasar tersebut menjadi faktor pendorong dan lahirnya inspirasi Muhammad untuk berdagang. Inspirasi

${ }^{30}$ Menurut arkeolog Saudi Arabia, pasar Ukaz yang buka pertama kali pada 500 sebelum Masehi berakhir hingga $760 \mathrm{M}$. Sejak itu pasar tersebut tidak beroperasi lagi. Pasar ini diaktifkan lagi setelah berselang 1300 tahun oleh Gubernur Mecca, Pangeran Khamid al-Faisal. M. Suyanto, Muhammad Business Strategy and Ethics, h. 111. 
untuk berdagang tidak hanya diperoleh dari pagelaran pasar-pasar tradisional, namun ia peroleh dari pasar dunia, seperti keikutsertaan Muhammad dalam rombongan kafilah perdagangan menuju Syam.

Ketika Abu Thalib hendak melakukan perdagangan ke Syam, Muhammad menyampaikan keinginannya berkali-kali kepada pamannya agar diperkenankan ikut. Namun keinginan itu selalu ditolak pamannya dengan alasan perjalanan yang ditempuh jauh dan demi keselamatan dirinya, mengingat Muhammad dipandang belum cukup umur untuk mengembara. Keinginan Muhammad tidak terbedung lagi. Ia menyusul dan mendesak pamannya yang waktu itu bersiap-siap melakukan perjalanan ke Syam. Saat itu Muhammad merasa senang karena ia akan memperoleh pengalaman selama menempuh perjalanan. Tabel 2 menunjukkan beberapa pasar yang dikunjungi oleh Muhammad sebelum menjadi Nabi.

Tabel 2.

Pasar yang Dikunjungi Muhammad sebelum Menjadi Nabi

\begin{tabular}{|l|l|l|l|}
\hline Nama Pasar & \multicolumn{1}{|c|}{ Waktu Festival } & \multicolumn{1}{|c|}{ Lokasi } & \multicolumn{1}{c|}{ Ket. Kunjungan } \\
\hline Ukaz & 1-20 Dzul Qa'dah & $\begin{array}{l}\text { al-Athdia } \\
\text { (antara Makkah-Thaif) }\end{array}$ & $\begin{array}{l}\text { Tujuh kali } \\
\text { (qabl wa ba'd al bi'tsah) }\end{array}$ \\
\hline Majinna & 21-30 Dzul Qa'dal & antara Makkah-Thaif & Beberapa kali \\
\hline Dzul Majaz & 1-7 Dzul Hijjah & $\begin{array}{l}\text { antara Ukaz dan } \\
\text { Makkah }\end{array}$ & Beberapa kali \\
\hline Mushaqqar & 1-30 Jumadil Awal & Hijar Bahrain & Beberapa kali (usia 18-25 th) \\
\hline Basra & Sepanjang tahun & Syam & Usia 12 tahun (tahun 583 M) \\
\hline
\end{tabular}

Sumber: Dikembangkan untuk penelitian.

Abu Thalib merupakan salah satu keluarga yang selalu mendorong Muhammad untuk menjadi pebisnis. Ketika Abu Thalib sudah tua, ia memanggil Muhammad dan berkata: "Hai anak saudaraku, sebagaimana telah kamu ketahui bahwa pamanmu ini sudah tidak punya kekayaan lagi, padahal keadaan sudah sangat mendesak, maka alangkah baiknya jika kamu mulai berniaga dan sedikit demi sedikit hasilnya dapat kamu pergunakan untuk kepentinganmu sehari-hari" ${ }^{31}$ Muhammad mengikuti nasihat pamannya, dan profesi pebisnis ini yang kemudian ia tekuni hingga ia menjadi seorang nabi.

${ }^{31}$ KH. Moenawar Cholil, Kelengkapan Tarikh Nabi Muhammad, Jil. 1, h. 83. 


\section{Faktor Beristri Khadijah}

Pada usia 25 tahun Muhammad menikah dengan Khadijah (40 tahun). Nama lengkap Khadijah adalah Khadijah binti Khuwailid ibn Asad ibn Abdul Uza ibn Qushay ibn Kilab. Khadijah dijuluki Umm al-Mu'minin al-Kubra. Ia anak Khuwailid dan cicit Qusay. Ia berasal dari kalangan bangsawan dan keluarga kaya. Ia tercatat sebagai wanita terkaya di Makkah. Meskipun sebagai wanita ia dikenal pemberani, disamping sikap lainnya yang toleran dan memiliki kepekaan sosial atas lingkungan sekitarnya. Ia sebagai pengusaha yang memiliki kemampuan manajerial baik. Ia mempercayakan barang dagangannya kepada anak buahnya.

Sebelum menikah dengan Muhammad, Khadijah tercatat dua kali menikah. Pernikahan pertama dengan Abu Halal al-Nabbasy bin Zurarah. Hasil pernikahannya dikarunia seorang anak bernama Halal. Setelah suaminya meninggal, Khadijah menikah untuk kedua kalinya dengan Atiq bin Abid alMakhzumy. Sejak perkawinan yang kedua ini, Khadijah menjadi orang sukses. Kesuksesannya meruapakan kerja kerasnya dan berkat bantuan orang tuanya. Keberhasilan bisnisnya dibantu oleh beberapa orang karyawannya. Sebagai pekerja keras ia memenej barang dagangannya dengan baik. Ia juga tidak segan-segan memberikan kepercayaan kepada karyawannya berdagang dengan membawa barang dagangannya. Tidak lama kemudian, suaminya (Atiq) meninggal dunia.

Sepeninggal wafat suaminya, Khadijah tetap bersemangat untuk mengelola bisnisnya. Semakin lama ia semakin sukses dan terkenal di Makkah. Ia dikenal sebagai janda yang cantik, terhormat dan kaya raya. Banyak laki-laki yang ingin mempersuntingnya, namun Khadijah menolaknya. Dengan kesibukan bisninya, Khadijah tidak begitu tertarik dengan laki-laki yang berusaha melamarnya atau relasi bisnisnya. Perkawinanya mulai dibina lagi ketika ia mempersunting Muhammad.

Awal perkenalan khadijah dengan Muhammad, ketika Abu Thalib ingin memperkerjakan Muhammad kepada Khadijah, meskipun Khadijah sudah mendengar berita tentang Muhammad yang dijuluki al-Amin. Muhammad diajak Abu Thalib untuk menemui saudagar kaya raya Khadijah untuk melamar sebagai salah satu karyawannya. Abu Thalib melamarkan Muhammad sebagai karyawan dengan imbalan tinggi. Permintaan Abu Thalib diterima, meskipun gaji yang dimintanya empat kali lipat dari gaji yang Khadijah berikan kepada karyawan lain. Bagi Khadijah permintaan gaji besar tidak mem- 
beratkannya karena Khadijah sudah mengenal Muhammad. Muhammad dikenal sebagai orang yang jujur dalam perkataan dan perbuatannya. Selama menjadi karyawannya, cerita tentang keberhasilan Muhammad berdagang sampai terdengar Khadijah. Beberapa karyawannya menceritakan pengalamannya selama mendampingi Muhammad berdagang. Mendengar perilaku baiknya, muncul keinginan Khadijah mempersuami Muhammad.

Pernikahan Muhammad dilaksanakan ketika ia berusia 25 tahun dan Khadijah berusia 40 tahun. Pada waktu menikah Muhammad belum berhasil menjadi pebisnis. Hasil kerjanya hanya cukup untuk memenuhi kebutuhannya. Ia belum mempunyai harta, apalagi untuk menikah. Dalam satu riwayat Khadijah mengutus Nafisah binti Umayyah ${ }^{32}$ menemui Muhammad untuk menjajaki keadaan Muhammad. Nafisah berkata kepada Muhammad: "Apa yang mencegahmu untuk menikah?" Muhammad menjawab: "Saya tidak punya apa-apa? Setelah melibatkan orang-orang dekat (keluarga) Muhammad dan atas persetujuannya pernikahan dilangsungkan.

Pernikahan Muhammad dengan Khadijah merupakan pasangan yang sangat cocok. Sewaktu Muhammad masih menjadi karyawan Khadijah, ia dikenal sebagai pekerja keras, ulet dan jujur. Sementara Khadijah adalah janda kaya raya. Dengan demikian maka Muhammad harus berjuang keras untuk menjalankan kekayaan yang dimiliki istrinya. Manajemen pengelolaan harta ia lakukan dengan profesional. Ia belajar dari istrinya dan lingkungannya. Ini merupakan faktor kuat yang mendorong Muhammad menjadi pebisnis karena tidak mungkin kekayaan yang dimiliki istrinya tidak terurus. Muhammad harus pandai memenej barang dagangan dengan dengan baik disamping itu ia harus memperhatikan kesejahteraan karyawan yang dimilikinya.

\section{E. Etika Bisnis Muhammad}

Keberhasilan Muhammad dalam berbisnis dipengaruhi oleh kepribadian diri Muhammad yang dibangunnya atas dasar dialogis realitas sosial masyarakat Jahiliyyah dengan dirinya. Kemampuan mengelola bisnis tanpak pada keberaniannya membawa dagangan Khadijah dan ditemani hanya seorang karyawan (Maisarah). Jika ia tidak memiliki pengalaman dan kemampuan berdagang maka ia hanya akan menjadi pendamping Maisarah. Ia bertang-

32 Muhammad bin Alwi al-Maliky, al-Bushrā fi Manāqib al-Sayyidah Khadījah al-Kubrā, (Surabaya: Barar al-Tsaqaf, 1994), h. 12. 
gungjawab penuh atas semua dagangan milik Khadijah. Demikian juga barang-barang dagangannya yang ia bawa dari pasar ke pasar atau tempattempat festival perdagangan. Berikut beberapa etika bisnis Muhammad dalam praktek bisnisnya antara lain:

Pertama, kejujuran. Dalam melakukan transaksi bisnis Muhammad menggunakan kejujuran sebagai etika dasar. Gelar al-Aminn (dapat dipercaya) yang diberikan masyarakat Makkah berdasarkan perilaku Muhammad pada setiap harinya sebelum ia menjadi pelaku bisnis. Ia berbuat jujur dalam segala hal, termasuk menjual barang dagangannya. Cakupan jujur ini sangat luas, seperti tidak melakukan penipuan, tidak menyembunyikan cacat pada barang dagangan, menimbang barang dengan timbangan yang tepat, dan lain-lain.

Kejujuran Muhammad dalam bertransaksi dilakukan dengan cara menyampaikan kondisi riil barang dagangannya. Ia tidak menyembunyikan kecacatan barang atau mengunggulkan barang daganganya, kecuali sesuai dengan kondisi barang yang dijualnya. Praktek ini dilkaukan dengan wajar dan menggunakan bahasa yang santun. Beliau tidak melakukan sumpah untuk menyakinkan apa yang dikatakannya, termasuk menggunakan nama Tuhan. Ketika Muhammad menjual dagangan di Syam, ia pernah bersitegang dengan salah satu pembelinya terkait kondisi barang yang dipilih oleh pembeli tersebut. Calon pembeli berkata kepada Muhammad, "Bersumpahlah demi Lata dan Uzza!" Muhammad menjawab, "Aku tidak pernah bersumpah atas nama Lata dan Uzza sebelumnya." Penolakan Muhammad dimaklumi oleh pembeli tersebut, dan sang pembeli berkata kepada Maisarah, "Demi Allah, ia adalah seorang Nabi yang tanda-tandanya telah diketahui oleh para pendeta kami dari kitab-kitab kami." ${ }^{33}$

Dalam konteks sekarang, sekilas kedengarannya aneh bahwa kejujuran merupakan sebuah prinsip etika bisnis karena mitos keliru bahwa bisnis adalah kegiatan tipu menipu untuk meraup untung besar. Memang etika ini agak problematic karena masih banyak pelaku bisnis sekarang yang mendasarkan kegiatan bisnisnya dengan cara curang, karena situasi eksternal atau karena internal (suka menipu). Sering pedagang menyakinkan katakatanya disertai dengan ucapan sumpah (termasuk sumpah atas nama

${ }^{33}$ Mahdi Rizqullah Ahmad, al-Sirah al-Nabawiyyah fi Dhauq'i al-Mașādir al-Așliyyah: Dirasah Tahlïliyyah, terj. Yessi HM., (Jakarta: Qisthi Press, 2006), h. 157. 
Tuhan). Padahal kegiatan bisnis yang tidak menggunakan kejujuran sebagai etika bisnisnya, maka bisnisnya tidak akan bisa bertahan lama. Para pelaku bisnis modern sadar bahwa kejujuran dalam berbisnis adalah kunci keberhasilan, termasuk untuk mampu bertahan dalam jangka panjang dalam suasana bisnis yang serba ketat dalam bersaing.

Tradisi buruk sebagian bangsa Arab adalah tidak bersikap jujur (berbohong) dalam menjajakan barang dagangannya. Barang yang cacat tidak diberitahukan kepada calon pembelinya. Penimbangan barang tidak tepat atau penimbangan barang antara barang kering dan basah. Cara-cara perdagangan mereka masih terdapat unsur penipuan. Dalam kondisi praktek mal-bisnis (kecurangan bisnis) seperti ini, Muhammad muncul sebagai pelaku bisnis yang mengkedepankan kejujuran, yang kemudian hari mengantarkannya sebagai pemuda yang memiliki gelar al-amin.

Kedua, amanah. Amanah adalah bentuk masdar dari amuna, ya'munu yang artinya bisa dipercaya. Ia juga memiliki arti pesan, perintah atau wejangan. Dalam konteks fiqh, amanah memiliki arti kepercayaan yang diberikan kepada seseorang berkaitan dengan harta benda. Muhammad dalam berniaga menggunakan etika ini sebagai prinsip dalam menjalankan aktivitasnya. Ketika Muhammad sebagai salah satu karyawan Khadijah, ia memperoleh kepercayaan penuh membawa barang-barang dagangan Khadijah untuk dibawa dan dijual di Syam. Ia menjaga barang dagangannya dengan baik selama dalam perjalanan. Dengan ditemani Maisarah, Muhammad menjual barang-barang tersebut sesuai dengan amanat yang ia terima dari Khadijah. Agar barang dagangannya aman selama dalam perjalanan, Muhammad bersama-sama dengan rombongan kafilah dagang. Selama dalam perjalanan kafilah-kafilah tersebut merasa aman karena dikawal oleh tim keamanan atau sudah ada jaminan dari suku tertentu.

Setelah sampai di kota tujuan, Muhammad dan Maisarah membongkar barang dagangannya. Mereka berdua menggelar barang dagangannya dan menawarkan barang tersebut kepada para pengunjuang. Barang dagangan tersebut habis terjual. Sebelum pulang Muhammad membeli beberapa barang untuk dijual di Makkah. Dari barang yang dibelinya, Muhammad juga memperoleh keuntungan. Tanpa diduga keuntungan Muhammad sangat besar dan membuat majikannya puas. Hasil keuntungan tersebut ia laporkan dan serahkan kepada Maisarah tanpa kurang sedikitpun. Setelah itu Muhammad diberi upah besar sesuai dengan perjanjiannya, yakni empat kali dari gaji yang biasanya Khadijah berikan kepada karyawan lainnya. 
Ketiga, tepat menimbang. Etika bisnis Muhammad dalam menjual barang harus seimbang. Barang yang kering bisa ditukar dengan barang yang kering. Penukaran barang kering tidak boleh dengan barang yang basah. Demikian juga dalam penimbangan tersebut seseorang tidak boleh mengurangi timbangan. Dalam transaksi Muhammad menjauhi apa yang disebut dengan muzabana dan muhaqala. Muzabana adalah menjual kurma atau anggur segar (basah) dengan kurma atau anggur kering dengan cara menimbang. ${ }^{34}$ Muzabana pada dasarnya adalah menjual sesuatu yang jumlahnya, berat atau ukurannya tidak diketahui dengan sesuatu yang jumlahnya, berat atau ukurannya diketahui dengan jelas. Muhaqala adalah jual beli atau penukaran antara gandum belum dipanen dengan gandum yang sudah digiling atau menyewakan tanah untuk ditukarkan dengan gandum.

Apa yang dilakukan Muhammad di pasar Ukaz, Majinna, dan pasar-pasar lainnya adalah menjual beberapa barang, seperti kurma, anggur, gandum dan sejenisnya. Muhammad menimbang berat tersebut sesuai dengan ukurannya. Ia tidak mengurangi sedikitpun, sehingga kejujuran dan ketepatannya dalam menimbang sudah tersebar dimana-mana. Jika orang membeli barang dari Muhammad, mereka tidak ragu atas timbangannya..

Keempat, gharar. Gharar menurut bahasa berarti al-khatar yaitu sesuatu yang tidak diketahui pasti benar atau tidaknya. Dalam akad, gharar bisa berarti tampilan barang dagangan yang menarik dari sigi zhahirnya, namun dari sisi substansinya belum tentu baik. Dengan kata laian gharar adalah akad yang mengandung unsur penipuan karena tidak adanya kepastian, baik mengenai ada atau tidak adanya objek akad, besar kecilnya jumlah, maupun kemampuan menyerahkan objek yang disebutkan dalam akad tersebut. Dalam prakteknya Muhammad menjauhi praktek gharar, karena memuka ruang perselisihan antara pembeli dan penjual. Muhammad juga melarang penjualan secara urbun (bai' al-urbun). Muhammad melarang penjualan dengan lebih dahulu memberikan uang muka (panjar) dan uang itu hilang jika pembelian dibatalkan. Penjualan yang menyertai urbun adalah seorang pembeli atau penyewa mengatakan:" Saya berikan lebih dahulu uang muka kepada Anda. Jika pembelian ini tidak jadi saya teruskan, maka uang muka itu hilang, dan menjadi milik Anda. Jika barang jadi dibeli maka uang muka itu diperhitungkan dari harga yang belum dibayar."

${ }^{34}$ Imam Malik, al-Muwatta', (Jakarta: Rajagrafindo Persada, 1999), h. 343. 
Cakupan gharar ini sangat luas. Pertama, ketidakmampuan penjual untuk menyerahkan objek akad pada waktu terjadi akad, baik objek akad itu sudah ada atau belum ketika akad berlangsung, seperti menjual janin yang masih ada dalam perut binatang ternak. Kedua, menjual barang yang tidak berada di bawah kekuasaannya, seperti menjual barang kepada orang laian sementara barang yang akan dijual belum diterima dan masih berada di penjual sebelumnya. Hal ini tidak dibenarkan karena boleh jadi barang itu mengalami perubahan atau rusak. Ketiga, tidak adanya kepastian tentang jenis pembayaran atau jenis benda yang dijual. Barang dagangan dan pembayarannya kabur tidak jelas. Keempat, tidak adanya kepastian tentang sifat tertentu dari benda yang dijual, seperti penjual berkata, "Saya jual kepada Anda baju yang ada di rumah saya." Penjual tidak tegas menjelaskan baju yang mana, warna dan ukurannya, dan ciri-ciri lainnya. Kelima, tidak tegas jumlah harganya. Keenam, tidak tegas waktu penyerahan barangnya. Ketujuh, tidak adanya ketegasan bentuk transaksi. Kedelapan, tidak adanya kepastian objek, seperti adanya dua objek yang dijual dengan kualitas yang berbeda dengan harga sama dalam satu transaksi. Penjualan ini tidak tegas objek yang akan dijual. Kesembilan, kondisi objek akad tidak dapat dijamin kesesuaiannya dengan yang ditentukan dalam transaksi. ${ }^{35}$ Cara penjualan sebagaimana disebutkan di atas tidak sesuai denga etika Muhammad dalam berbisnis.

Kelima, tidak melakukan penimbunan barang. Dalam bahasa Arab penimbunan barang disebut ihtikar. Penimbunan ini tidak diperbolehkan karena akan menimbulkan kemadharatan bagi masyarakat karena barang yang dibutuhkan tidak ada di pasar. Tujuan penimbunan dilakukan dengan sengaja sampai dengan batas waktu untuk menunggu tingginya harga barang-barang tersebut. Muhammad dalam praktek bisnisnya menjauhi tindakan penimbunan. Barang dagangan yang dibawanya selalu habis. Bahkan jika perlu barang-barang dagangan yang dimiliki oleh Khadijah akan dijual semuanya. Namun karena keterbatasan alat transportasi Muhammad membawa barang secukupnya.

Muhammad sadar bahwa kebutuhan sehari-hari harus didistribusikan dengan baik. Barang dagangan tidak boleh disimpan lama sehingga barang tersebut langka dijumpai di pasar. Berdasarkan teori pasar, jika barang sedikit dan permintaan pasar besar maka harga barang menjadi tinggi. Jika

35 Tim Redaksi Ichtiar Baru Van Hoeve, Ensiklopedi Hukum Islam, Jil. 2, (Jakarta: Ichtiar Baru Van Hoeve, 2001), h.399-400. 
harga tinggi maka keuntungan besar dapat diperoleh para pedagang. Namun konsumen akan mengalami kesulitan, khususnya mereka yang tidak mampu membayar sesuai dengat harga tinggi yang menjadi tuntutan pasar.

Dalam tradisi Jahiliyyah, penimbunan barang merupakan salah satu strategi untuk memperoleh keuntungan besar. Mereka menunggu waktuwaktu yang strategis, misalnya pada masa festival pasar Ukaz. Pasar ini merupakan pasar yang besar yang digelar setahun sekali, tepatnya pada awal hingga pertengahan Dzul Qa'dah. Beberapa saat kemudian festival pasar berpindah ke Majanna dan Dzul Majid. Tradisi-tradisi penimbunan barang ini seolah-olah sudah terjadwal dari bulan ke bulan.

Keenam, tidak melakukan al-ghab dan tadlīs. Al-ghab artinya al-khada (penipuan), yakni membeli sesuatu dengan harga yang lebih tinggi atau lebih rendah dari harga rata-rata. Sedangkan tadlīs yaitu penipuan yang dilakukan oleh pihak penjual atau pembeli dengan cara menyembunyikan kecacatan ketika terjadi transaāksi. Dalam bisnis modern perilaku al-ghab atau tadlīs bisa terjadi dalam proses mark up yang melampaui kewajaran atau wan prestasi.

Rahasia kesuksesan Muhammad dalam praktek bisnisnya dilakukan dengan menerapkan harga yang sedang tidak terlalu tinggi dan tidak terlalu rendah. Baginya yang penting adalah sirkulasi barang diantara para pedagang dan pembeli. Jangan sampai barang hanya berputar pada sekelompok tertentu saja. Tetepai barang tersebut terdistribusi ke lapaisan masyarakat. Jika perputaran baārang berjalan dengan baik, maka aktivitas bisnis menjadi stabil, dan harga dapat dijangkau oleh masyarakat. Dalam hal ini Muhammad juga menjual sesuai dengan harga. Ia tidak memanipulasi harga dan tidak kompromi kepada pembeli yang menaikkan harga agar ia memperoleh keuntungan. Mark up dilakukan oleh pembeli ketika ia memperoleh pesanan dari pihak lain.

Etika Muhammad dalam menyampaikan informasi seputar barang dagangannya dilakukan secara rinci. Ia tidak menyembunyikan kecacatan barang dagangannya. Jika pembeli meminta atas kejujuran Muhammad atas kondisi barang dagangannya dengan sumpah atas nama Tuhan, Muhammad selalu menolaknya. Baginya berkata jujur merupakan kunci kesuksesan bisnis.

Ketujuh, saling menguntungkan. Prinsip ini mengajarkan bahwa dalam bisnis para pihak harus merasa untung dan puas. Etika ini pada dasarnya mengakomodasi hakikat dan tujuan bisnis. Seorang produsen ingin memperoleh keuntungan, dan seorang konsumen ingin memperoleh barang yang 
bagus dan memuaskan, maka sebaiknya bisnis dijalankan dengan saling menguntungkan.

Dalam berniaga Muhammad mendeskripsikan barang dagangan yang akan dibeli oleh konsumen. Jika barang ada cacatnya Muhammad mengatakannya terus teras. Jika barang dagangan bagus, ia mengatakannya sesuai dengan keadaannya. Bahkan dalam satu riwayat, Muhammad memberitahukan harga pembeliannya, dan seberapa banyak konsumen akan memberikan keuntungan diserahkan sepenuhnya kepada konsumen. Atas dasar sikap Muhammad ini, konsumen yang merasa puas atas barang yang dibelinya, ia akan memberikan keuntungan atau jasa lebih karena perasaan puas.

\section{F. Legislasi dan Pesan Muhammad dalam Berbisnis}

Muhammad menjadi pelaku bisnis sangat dipengaruhi oleh lingkungannya sejak ia kecil hingga dewasa, dan menikah dengan Khadijah. Pengalaman berbisnis yang diperolehnya sebelum ia menjadi Rasul merupakan hasil pergulatannya dengan realitas sosial. Dan setelah ia menjadi Rasul, sebagian pengalamannya dituangkan dalam sabdanya, yang disebut dengan hadits. Ada beberapa pesan Rasulullah dalam bisnis, antara lain:

Pertama, jual beli harus dilakukan atas dasar kesepakan ('an tarāḍin) antara penjual dan pembeli.

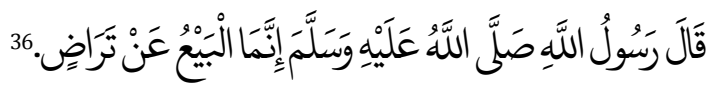

Rasulullah bersabda: "Sesungguhnya jual beli itu hanya sah jika dilakukan atas dasar suka sama suka ('an tarāḍin)."

Kedua, barang yang menjadi objek transaksi harus suci.

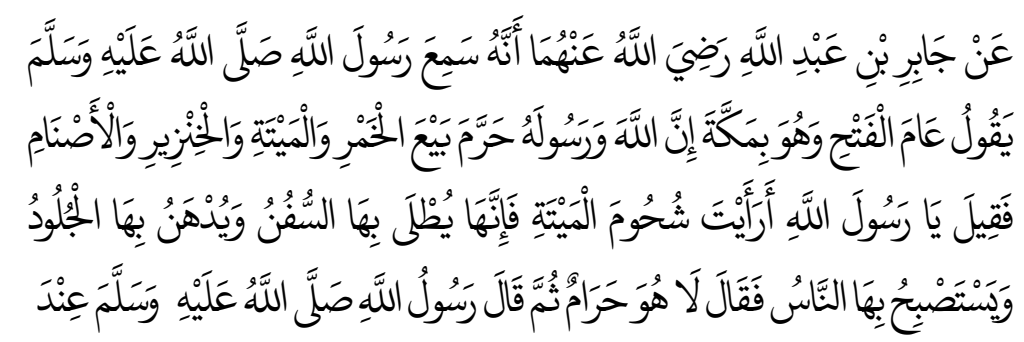

${ }^{36}$ Hadits riwayat Ibnu Majah, no. 2186. 


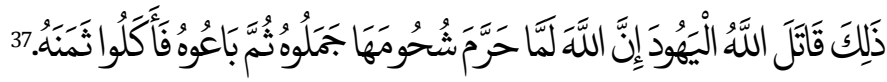

Dari Jabir bin Abdullah ra. bahwa ia mendengar Rasulullah bersabda pada waktu fath al-Makkah: "Sesungguhnya Allah dan Rasul-Nya telah mengharamkan menjual khamar, bangkai, daging babi, dan berhala." Kemudian dikatakan kepada beliau: "Bagaimana pendapatmu tentang lemak bangkai yang dapat dijadikan penambal perahu, pencat kulit dan yang dijadikan minyak lampu oleh manusia?" Beliau menjawab: tidak boleh, hukumnya tetap haram." Kemudian Rasulullah bersabda: "Sesungguhnya Allah setelah mengharamkan kepada orang-orang Yahudi lemak bangkai, mereka mengolah lemak tersebut, kemudian menjualnya dan memakan uang (harga)-nya."

Ketiga, tidak ada unsur penipuan (gharar).

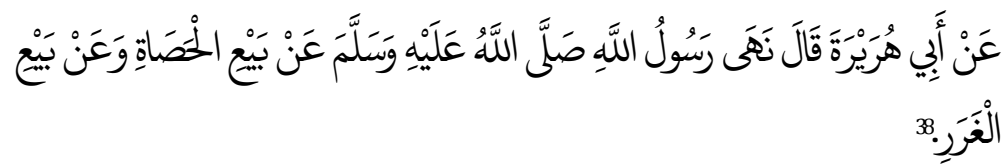

Dari Abu Hurairah bahwa Nabi SAW melarang jual hașah dan jual beli gharar (yang belum jelas harga, barang, waktu, dan tempatnya).

Keempat, barang jelas posisi dan ukurannya (berat - jumlah).

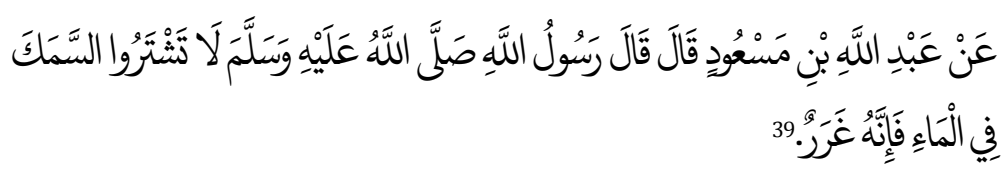

Dari Abdullah bin Mas'ud berkata, bahwa Rasulullah bersabda: "Janganlah kalian membeli ikan dalam air karena padanya terkandung unsur penipuan."

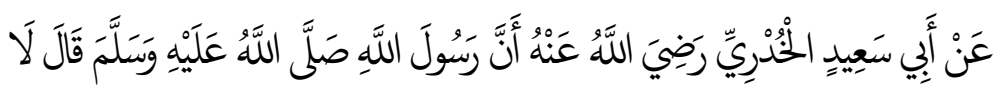

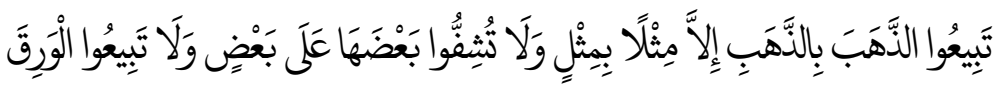

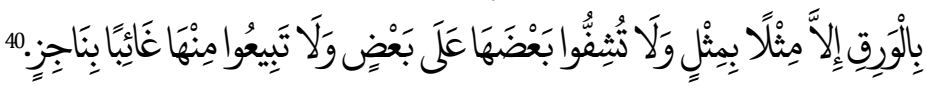

\footnotetext{
${ }^{37}$ Hadits riwayat Bukhari, no. 2082.

${ }^{38}$ Hadits riwayat Muslim, no. 2783.

${ }^{39}$ Hadits riwayat Ahmad, no. 3496.

${ }^{40}$ Hadits riwayat Bukhari, no. 2031.
} 
Diriwayatkan dari Abu Sa'id al-Khudry bahwa Rasulullah bersabda: "Janganlah kalian menjual emas dengan emas kecuali bila sama ukurannya. Janganlah kalian melebihkan sebagian terhadap sebagian yang lain. Janganlah kalian menjual uang kertas dengan uang kertas kecuali jumlahnya sama, dan janganlah kamu lebihkan sebagian terhadap sebagian yang lain. Dan janganlah kalian menjual barang yang belum jelas wujudnya dengan barang yang nyata wujudnya."

Kelima, barang yang dijual merupakan hak milik.

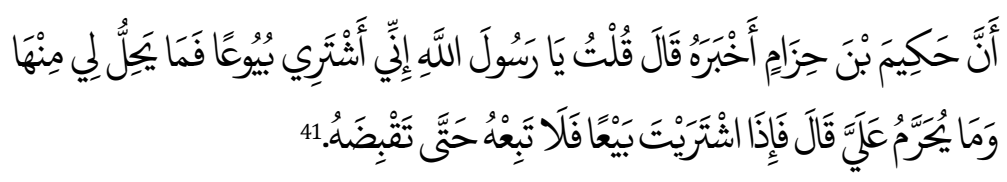

Sesungguhnya Hakim bin Hizam telah menceritakannya, berkata: "Wahai Rasulullah, sesungguhnya saya telah membeli suatu barang, apakah yang halal untuk saya lakukan dan apa yang haram?" Beliau menjawab: "Apabila engkau membeli sesuatu janganlah engkau jual sampai engkau sendiri memegangnya."

Keenam, segera membayarkan upah.

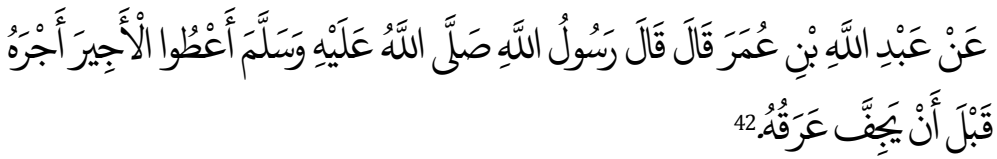

Diriwayatkan dari Abdillah bin 'Umar berkata, Rasulullah bersabda: "Berikanlah upah pekerja sebelum kering keringatnya."

Ketujuh, tidak berkhianat kepada relasi bisnis.

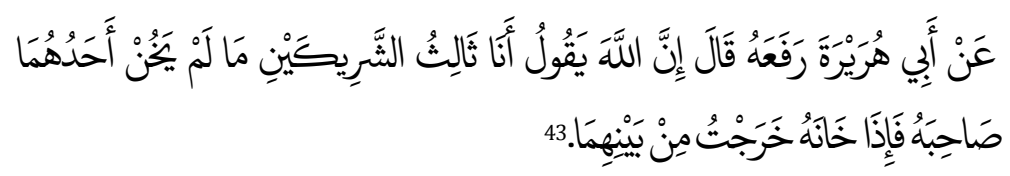

Dari Abu Hurairah-semoga Allah mengangkat derajatnya - bahwa Allah berfirman dalam hadits qudsi: "Aku adalah pihak yang ketiga dari dua orang yang berserikat selama salah seorang diantaranya tidak mengkhianati temannya. Bila salah seorang diatara keduanya berkhianat, Aku keluar dari perselisihan keduanya."

\footnotetext{
${ }^{41}$ Hadits riwayat Ahmad, no. 14777.

${ }^{42}$ Hadits riwayat Ibnu Majah, no. 2434.

${ }^{43}$ Hadits riwayat Abu Daud, no. 2936.
} 
Kedelapan, tidak menimbun barang.

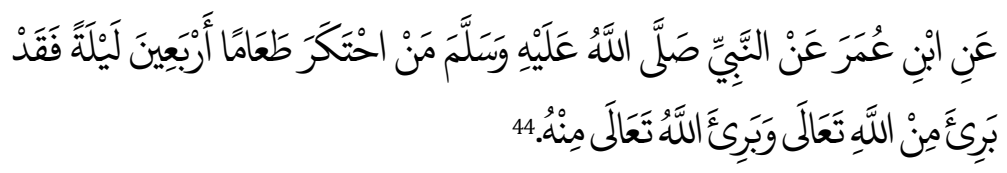

Dari Ibn 'Umar (bahwa) Nabi SAW (bersabda): "Barang siapa yang menimbun makanan selama empat puluh hari (dengan tujuan menaikkan harga) ia telah berlepas diri dari Allah, dan Allah juga telah berlepas diri darinya."

Kesembilan, tidak melakukan transaksi ribawi.

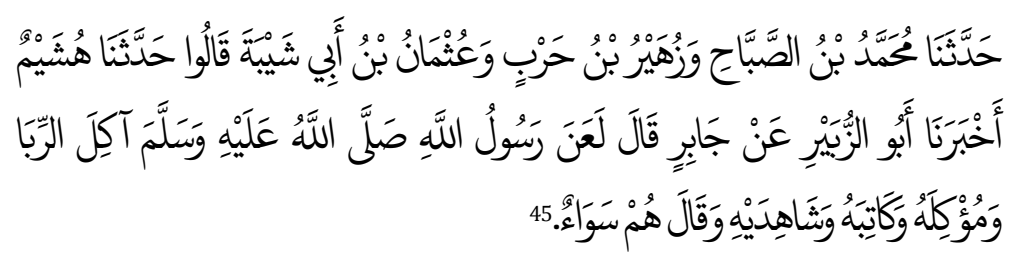

Diriwayatkan dari Jabir, ia berkata bahwa Rasulullah mengutuk pemakan riba, orang yang memberi pinjaman, orang yang mewakilinya (orang yang utang), orang yang mencatatnya, dan orang yang menjadi saksinya. Dan ia berkata: "Mereka semuanya sama (hukumnya)."

\section{G. Kesimpulan}

Dari penelusuran sejarah yang dilakukan penulis, maka dapat ditemukan bahwa etika bisnis yang dimiliki oleh Nabi Muhammad SAW adalah bersikap jujur, amanah, tepat dalam menimbang, menjauhi gharar, tidak menimbun barang, tidak melakukan al-ghab dan tadlis, dan saling menguntungkan (mutual benefit principle) antara penjual dan pembeli. Pola bisnis yang dipraktikkan Nabi Muhammad SAW ini tentu perlu diadaptasi oleh para pebisnis di masa kini yang terkadang mudah keluar dari etika-etika seperti yang dipraktikkan oleh Nabi SAW. [w]

\footnotetext{
${ }^{44}$ Hadits riwayat Ahmad, no. 4648.

${ }^{45}$ Hadits riwayat Muslim, no. 2995.
} 


\section{BIBLIOGRAFI}

Abdul Karim, M., History of the Muslim Thought and Civillization, edisi bahasa Indonesia, Sejarah Pemikiran dan Peradaban, terj. Pustaka Book Publisher, Yogyakarta: Pustaka Book Publisher, 2007.

Abdul Aziz Azhim bin Badawi, al-Wajiz fi Fiqh al-Sunnah wa '-Kitāb al-'Azīz: Kitab alBuyu,'(terj. Hayik el Bahja), Bogor: Media Tarbiyah, 2008.

Achmad Charris Zubair, Kuliah Etika, Jakarta: Rajawali Press, 1995.

Achmad Djunaidi dan Thobieb al Asyhar, The Secret of Success Khadijah, Jakarta: GP Press, 2008.

Amirullah dan Imam Harjanto, Pengantar Bisnis, Yogyakarta: Graha Ilmu, 2005.

Consuello G. Sevilla, dkk, Pengantar Metode Penelitian, Yogyakarta: UII Press, 1993.

Faisal Badroen (ed.), Etika Bisnis dalam Islam, Jakarta: Prenada Media Group, 2006.

FR. Faridl (ed.), Islamic Principles of Business Organizational and Management, New Delhi: Qazi Publeshers and Distributors, 1995.

H. Rus'an, Lintasan Sejarah Islam di Zaman Rasulullah SAW, Semarang: Wicaksana, 1981.

Hamid Hamidullah, Fikih Islam dan Hukum Romawi, Yogyakarta: Gama Media, 2003.

Hans Wehr, A Dictionary of Modern Written Arabic, London: MacDonald \& Evans Ltd, 1980.

Hariyono, Mempelajari Sejarah Secara Efektif; Jakarta: Pustaka Jaya, 1995.

Jaribah bin Ahmad al-Haritsi, al-Fiqh al-Iqtișadi li Amir al-Mu'minīn (terj. H. Asmuni Sholihan Z, Lc., Fiqih Ekonomi Umar bi al Khathab), Jakarta: Califa, 2006.

Kasmir, S.E., M.M., Etika Customer Service, Jakarta: Rajagrafindo Persada, 2006.

Khairul Amru Harahap, Rahasia Sukses Bisnis Khadijah, Jakarta: Qultumedia, 2008.

Lukman Fauroni, R., Etika Bisnis dalam al-Qur'an, Yogyakarta: LkiS, 2006.

Mahdi Rizqullah Ahmad, M., al-Sirah al-Nabawiyyah fi-Dhauq'i al-Mașadir al-Așliyyah: Dirasah Tahliliyyah, terj. Yessi HM., Jakarta: Qisthi Press, 2006.

Malik, Imam, al-Muwattata', Jakarta: Rajagrafindo Persada, 1999.

Walisongo, Volume 19, Nomor 1, Mei 2011 
Marzuki, Metodologi Riset, Yogyakarta: BPFE-UII,2000.

Moh. Nazir, Ph.D., Metode Penelitian, Bogor: Ghalia Indonesia, 2005.

Muhammad bin Alwi al-Maliky, al-Bushra fi Manāqib al-Sayyidah Khadījah al-Kubrā, Surabaya: Barar al-Tsaqaf, 1994.

Muhammad bin Yasar ibn Isaac, Sirah Ibn Ishaq, Surakarta: Muhammadiyah University Press, 2002.

Muhammad, Etika Bisnis Islami, Yogyakarta: UPP AMPYKPN, 2004.

Moenawar Chalil, KH., Kelengkapan Tarikh Nabi Muhammad, jilid 1, Jakarta: Gema Insani Press, 2006.

Shihab, M. Quraish, Wawasan al-Qur'an; Tafsir Maudhu'i atas Pelbagai Persoalan Umat, Bandung: Mizan, 1996.

"Etika Bisnis dalam Wawasan al-Qur'an," Jurnal Ulumul Qur'an, No. 3/VII/1997.

Sofyan Syafri Harahap, Akuntansi Islam, Jakarta: Bumi Aksara, 1997.

Sonny Keraf, A., Etika Bisnis Tuntutan dan Relevansinya, Yogyakarta: Kanisius, 1998.

Suyanto, M., Muhammad Business Strategy and Ethics, Yogyakarta: Andi Ofset, 2008.

Tim Redaksi Ichtiar Baru Van Hoeve, Ensiklopedi Hukum Islam, jilid 2, Jakarta: Ichtiar Baru Van Hoeve, 2001.

Webster's New Collegiatem Dictionary, USA: G. dan C.Merriam Company. 